\title{
THE WORK CULTURE OF SOUTH KOREAN COMPANIES IN INDONESIA
}

\section{Mochamad Mochklas ${ }^{1}$, Dwi Songgo Panggayudi ${ }^{2}$, Soenarto ${ }^{3}$}

${ }^{1}$ Faculty of Economics and Business, University of Muhammadiyah Surabaya, Indonesia, ${ }^{2}$ Faculty of Technical, University of Muhammadiyah Surabaya, Indonesia, ${ }^{3}$ Faculty of Economics, University of Maarif Hasyim Latif (UMAHA), Sidoarjo,

Indonesia.

Email: mmochklas@gmail.com

Article History: Received on $20^{\text {th }}$ July 2019, Revised on $30^{\text {th }}$ August 2019, Published on $26^{\text {th }}$ September 2019

Abstract

Research purpose: Analyzing the factors that influence the work culture of South Korean companies in Indonesia.

Methodology: The population in this study was employees who worked at a South Korean company in Surabaya. The sampling technique in this study is stratified random sampling. The appropriate data and can be processed as many as 229 people and the data were analyzed in a quantitative manner using SEM-AMOS version 20.0.

Main Findings: Work culture in South Korean companies in Indonesia, such as the harmonious relationship in the work culture of South Korean companies in Indonesia is more reflected in indicators of cooperation, work integrity is more reflected in indicators of honesty and further work discipline. reflected by indicators working on time. The work culture of South Kore an companies in Indonesia is more dominant in work integrity, which can encourage the quality and quantity of work produced.

Implications: Changing cultures requires enormous effort and requires the involvement of all elements in the organization. The role of the leader is very important in shaping the culture of the organization and is crucial in efforts to achieve predetermined goals. By knowing the factors that influence the work culture of South Korean companies in Indonesia, it is hoped that it can provide information to South Korean expatriates to improve the work culture of the company in maintaining its long-term business by building cooperation and relationships with local employees.

The novelty/originality of this study: The work culture of South Korean companies in Indonesia is more dominantly demonstrated by work integrity in shaping work culture. The work integrity of a South Korean company is demonstrated by indicators of honesty, confidence, and responsibility in completing work.

Keywords: South Korean Companies, Work Culture, Harmonious Relations, Work Integrity, Work Discipline, SEM-AMOS.

\section{INTRODUCTION}

In less than 30 years South Korea developed rapidly from an agricultural country to an industrial and trading country. South Korea is currently considered an economic model to be rivaled by other countries (Darini, 2010). The value of South Korea's investment is ranked fourth, where the largest investment sectors in 2014 were mining, basic metal industry, the rubber industry and leather industry (Sugiartiningsih, 2017).

Cross-cultural leadership competencies are needed in companies that operate internationally because it will greatly affect the interaction between managers assigned abroad with their local employees (Lumbanraja, 2008). Leadership influences organizational culture (Hakim, 2011) and plays an important role in improving organizational culture (Rasid, Manaf, \& Quoquab, 2013).

South Korean managers serving in Indonesia in labor-intensive companies are former technicians or laborers in South Korea, in their duties using authoritarian management methods that were often found in labor-intensive South Korean export companies (Hwan, 2011). The personnel policy in the South Korean management of senior employees is considered to have more capabilities than junior employees (Rahayu, 2009). South Korean managers control local employees when carrying out their duties on the grounds that they feel that the performance of local employees is still not good.

To achieve organizational goals and objectives organizational culture is very important (Nongo, 2012), culture for Korean business people has a strong influence in doing business (Lee, 2012). The existence of cultural differences in each individual in the organization, requires each individual to adapt to the existing norms and values of the organization in order to survive (Shahzad, et al., 2012), therefore the character of the Korean expatriate leadership style adapts to the culture of local employees (Risdanti, 2013).

The work culture of South Korean companies emphasizes more discipline regarding the achievement of targets that are flexible and tolerant (Puspitasari, Musadieq \& Prasetya, 2014). South Korea's work culture is influential in improving performance, also plays a role in mutual respect between Indonesian employees and expatriates in fostering loyalty from Indonesian employees (Mayangsari, Hamid, \& Prasetya, 2014). According to Wibawa, et al., (2014), organizational culture tends to external stakeholders, namely consumers, so it does not influence employee loyalty as internal stakeholders. 
Knowing the factors that affect the work culture of South Korea in Indonesia can inform South Korean expatriates in maintaining their long-term business in building cooperation and relationships with local employees. This study aims to analyze the factors that influence the influence of the culture of South Korean company organizations in Indonesia. Knowing the relationship is expected to be able to provide information to South Korean expatriates to improve their organizational culture in maintaining their long-term business by cooperating, building, maintaining relationships with local employees.

\section{REVIEW OF LITERATURE}

Culture is a variety of interactions of the characteristics of habits that affect groups of people in their environment, according to Beach (1993: 12) that culture is the core of the organization, such as the activity of giving commands and prohibitions and describing something done and not done that regulates the behavior of members organization argues that culture is the entirety of human behavior and the results of regular behavior by the behavior obtained by learning and the results are all arranged in people's lives.

\section{a. Organizational Culture}

Organizational culture is a system of beliefs, values, and norms developed in organizations that aims as a guide for members of the organization is behaving in overcoming all organizational problems both externally and internally (Mangkunegara, 2005: 113 ).

The application of organizational culture is very helpful for employees to do their jobs efficiently and effectively. The process of forming culture together increases an organization's ability to change (Purnama, 2013). The organizational culture that is not aligned with the company's strategy can cause a decrease in employee loyalty (Rachmadita, Kurniasih, \& Sandora, 2011). Management needs to motivate employees by creating systems and engineering in increasing employee productivity and competitiveness by providing incentives, education, and training (Shaban, et al. 2017).

Developing an appropriate organizational culture, the organization will be able to achieve the success that has an impact on increasing employee loyalty and a sense of belonging to the organization (Nongo, 2012), reduce turnover intention levels (Malik, 2014). Organizational culture that focuses on results accompanied by measurement of achievement goals in accordance with employees and causes resignation, but an objective management culture will prevent the desire of employees to move and can help keep employees with high skills (Kessler, 2014).

\section{b. Work Culture of South Korean Companies}

Corporates who control the economy of South Korea or Chaebol are well-known by applying company management based on Confucian values. The influence of Confucianism in South Korea's corporate culture can be seen from the existence of systems in organizations, paternalistic leadership, prioritizing loyalties and harmonious values, collectivism, family concepts, hierarchical structures and gender roles (Kee, 2008).

South Korea has a unique culture where it influences people's daily lives and business practices. Some of the main aspects of South Korea's unique culture that have a significant impact in doing business are Kibun, Inhwa, power distance and hierarchy, Confucianism and collectivism. All important aspects of Korean culture have a strong influence on how to do business (Lee, 2012), emphasizing discipline regarding the achievement of targets is flexible and tolerant (Puspitasari, Musadieq \& Prasetya, 2014).

\section{RESEARCH METHODS}

\section{a. Samples and Data Analysis}

The sampling technique in this study is disproportional stratified random sampling; this is due to population heterogeneity which includes gender, marital status, years of service and education. Where the population in this study are employees who work in South Korean companies in Surabaya after the data entered and passed the selection of the number of samples in this study that can be processed is 229 people. By sex men 176 (76.9\%) and women were $53(23.1 \%)$. Based on the marital status of unmarried many as $121(52.8 \%)$, and has been married $108(47.2 \%)$. Based on the working period of 1-3 years as many as $146(63.8 \%)$, 4-6 years $35(15.3 \%), 7-9$ years $14(6.1 \%)$, and above 10 years $34(14.8 \%)$. The education level of respondents at the Upper School level is 197 people (86\%) and the remaining 32 people (14\%) are diploma and undergraduate graduates.

Data analysis techniques in this study with a quantitative analysis approach, namely descriptive statistics and inferential statistics using the SEM analysis method using AMOS software version 20.

\section{b. Operational Definition of Research}

There are three dependent variables in this study namely the harmonious relationship (Kibun), work integrity (Inhwa) relationship developed according to Lee (2012) and work discipline developed according to Puspitasari, Musadieq \& Prasetya $\underline{(2014)}$. 
Harmonious relationship variables have indicators namely cooperation, dedication, perseverance, and creativity. the work integrity variable has indicators namely honesty, trust, and responsibility. work discipline variables have indicators namely compliance, timeliness, conformity of work procedures and compliance with regulations. Organizational culture has indicators, namely systems of beliefs, values and norms.

\section{RESEARCH RESULTS AND DISCUSSION}

Description of respondents 'answers is done by calculating the average value of respondents' answers to each indicator in each indicator. Respondents' answers for each indicator of the formation of South Korean company culture in Indonesia in this study are shown in table 1.

Table 1: Description of indicators for the formation of the work culture of South Korean companies in Indonesia

\begin{tabular}{|c|c|c|c|c|c|}
\hline Variable & Indicator & Statement & Mean & & $\begin{array}{l}\text { Std. } \\
\text { Deviation }\end{array}$ \\
\hline \multirow{4}{*}{$\begin{array}{l}\text { Harmonious } \\
\text { Relations } \\
\left(\mathrm{X}_{1}\right)\end{array}$} & $\mathrm{X}_{1.1}$ & $\begin{array}{l}\text { In the company, there is a good relationship } \\
\text { between colleagues }\end{array}$ & 4.17 & \multirow{4}{*}{4.07} & 0.861 \\
\hline & $\mathrm{X}_{1.2}$ & $\begin{array}{l}\text { For companies, employee service is seen as the } \\
\text { main source of competitive advantage }\end{array}$ & 3.77 & & 0.874 \\
\hline & $\mathrm{X}_{1.3}$ & Perseverance is needed in completing work & 4.10 & & 0.730 \\
\hline & $\mathrm{X}_{1.4}$ & $\begin{array}{l}\text { The company provides space for you to develop } \\
\text { creativity in completing work }\end{array}$ & 4.22 & & 0.876 \\
\hline \multirow{3}{*}{$\begin{array}{l}\text { Work } \\
\text { Integrity } \\
\left(\mathrm{X}_{2}\right)\end{array}$} & $\mathrm{X}_{2.1}$ & The company encourages you to work honestly & 4.27 & \multirow{3}{*}{4.21} & 0.691 \\
\hline & $\mathrm{X}_{2.2}$ & $\begin{array}{l}\text { The company gives you confidence in completing } \\
\text { work }\end{array}$ & 4.22 & & 0.620 \\
\hline & $\mathrm{X}_{2.3}$ & $\begin{array}{l}\text { The company assigns your duties } \\
\text { responsibilities according to your position }\end{array}$ & 4.13 & & 0.707 \\
\hline \multirow{4}{*}{$\begin{array}{l}\text { Work } \\
\text { Discipline } \\
\left(\mathrm{X}_{.3}\right)\end{array}$} & $\mathrm{X}_{3.1}$ & $\begin{array}{l}\text { In completing work you follow the instructions } \\
\text { that have been given }\end{array}$ & 3.96 & \multirow{4}{*}{4.11} & 0.616 \\
\hline & $\mathrm{X}_{3.2}$ & The company requires you to work on time & 4.10 & & 0.736 \\
\hline & $\mathrm{X}_{3.3}$ & $\begin{array}{l}\text { You always work based on established standard } \\
\text { operating procedures. }\end{array}$ & 4.07 & & 0.706 \\
\hline & $\mathrm{X}_{3.4}$ & $\begin{array}{l}\text { You are required to obey the rules set by the } \\
\text { company }\end{array}$ & 4.30 & & 0.641 \\
\hline Total & & & 4.12 & & \\
\hline
\end{tabular}

Source: Data processed by researchers

From Table 1, this shows that the harmonious relationship variable (X1) is more reflected by the cooperation indicator (X1.1). Good collaboration between colleagues who work inside and outside the work reflects the highest level of harmonious relationships at work. According to Gorda (2006: 190), a pleasant cooperative relationship will improve employee morale and sincerity, and also affect employee satisfaction. To support good cooperation, a comfortable work environment is needed, so that the workers can work optimally and productively.

Collaboration is shown by harmonious relations with superiors, coworkers who help each other at work. Harmonious work relationships with those who need work in the office and clear tasks in working in organizations affect the attitudes and behavior of employees at work (Syafitri and Heriyanto (2013)).

The working integrity variable (X2) is more reflected by the honesty indicator (X2.1). The encouragement from the leadership so that employees are honest in their highest work reflects work integrity. Work integrity is a tool that helps companies function effectively because work integrity is something that exists in a person. Integrity, honesty, and honesty are the keys to the process of generating trust through good positioning. It is a demand for good behavior that must be possessed by employees in working as morality, which is reflected in the thoughts, attitudes, and behavior shown by honesty, trust and responsibility. Trust is an effective tool in establishing and maintaining work relationships and personal relationships, especially in creating employee confidence in the leadership (Hassan, et al. 2012).

And work discipline variables (X3) are more reflected with indicators working on time (X3.2). Employees need to work on time reflects the highest level of work discipline. Application of organizational culture is very helpful for employees to do their jobs efficiently and effectively. A process of culture formation is needed together in order to improve the organization's ability to change in the face of competition (Purnama, 2013). 
From Table 1, it can be seen the highest perceptions of respondents regarding the work culture of South Korean companies in Indonesia on the work integrity variable, namely with an average value of 4.21 . Overall it is known that the average respondent's answer is 4.12. This value is included in both categories. From the data analysis of the standard deviation values generated on each indicator has a relatively low value, this shows that the same perceptions of employees regarding the work culture of South Korean companies in Indonesia.

The results of measuring the work culture indicators of South Korean companies in Indonesia are shown in Figure 1.

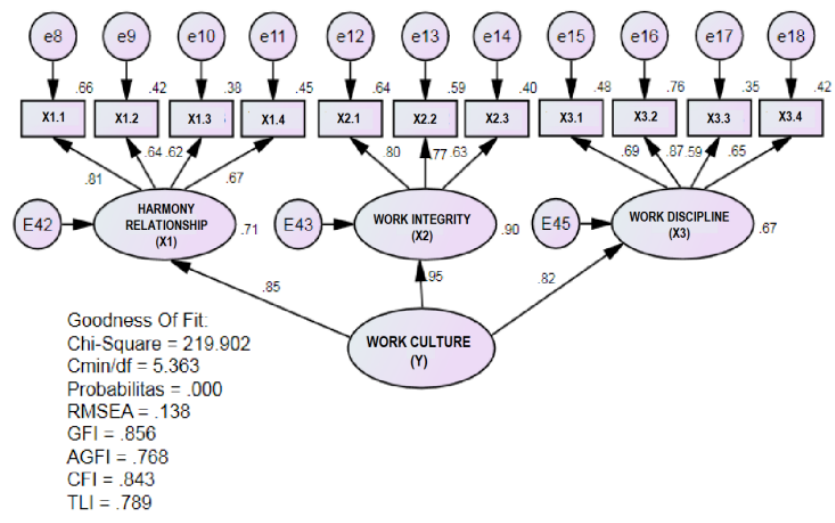

Figure 1: Confirmatory Factor Analysis of the work culture of a South Korean company in Indonesia Source: Processed data from researchers

From Figure 1, it can be seen that organizational culture is more reflected in the dimensions of work integrity (X2). The results of this study support the opinion of Rahayu (2009) which states that South Korean companies emphasize harmony, unity, and cooperation, creativity and development. The stability of South Korean companies is the main objective because of the background of the corporate culture, where harmony among members and the development of a stable overall organization are preferred over progressive morals and rapid growth. Lee (2012) argues that in doing business South Korean companies pay attention to all aspects of culture.

The results of this study indicate that the relationship and cooperation emphasized by South Korean expatriate leaders in carrying out the tasks of each department can work well. Good coordination between departments can run smoothly supported by a balance of feelings and good behavior that is owned by employees as morality at work. Management is expected to provide support and regulation of the organizational culture so that the company can run as expected. Where management regulation of organizational culture starts from developing work integrity in each department, function, and position of employees.

The function of work integrity can improve coordination in work units within the organization in an efficient and effective manner. The compactness of these units can encourage the quality and quantity of work produced (Robbins, 2003: 104). With employee integrity, it will strive to be a complete human being, who works well and performs its functions in accordance with what has been previously designed (Cloud, 2007:117).

Work integrity is a work culture in South Korean companies that are more moral in their work. Moral development for employees is very important in solving organizational problems quickly. Therefore, in carrying out work, employees are required to behave honestly and openly to all company issues such as administrative, production, quality or other problems.

Confucius is a South Korean culture that is embedded in human resource development and economic development. The motto of South Korean companies is almost all based on harmony and confusion, sincerity and weaving, creativity and development (Lee, 2012).

The results of this study differ from Mayangsari, Hamid \& Prasetya (2014) which states that South Korea's work culture emphasizes discipline in achieving company targets. The work culture in the form of discipline applied by South Korean expatriates is flexible and tolerant. Usually, a South Korean company in completing work does not really matter as long as the company's target is achieved. In the world work integrity can be interpreted as being consistent in acting in accordance with the code of ethics and workplace policies. Have an understanding and desire to adjust to the ethics and policies of the workplace and can act consistently to implement them. Integrity is one element in the character that underlies the emergence of recognition of professional attitudes. Can be a quality that underlies the emergence of other people's beliefs and becomes a benchmark for other members in testing the decision making in the work. 
The important role of integrity in the company is first, employees will work openly so that everyone knows and does not need to worry about hidden things. Second, to get the trust of others, especially for them in the position of managers and leaders. Third, integrity is a hallmark of ethical leadership both in the company, clients, colleagues, society, family, and also religion want leaders who they can trust.

\section{CONCLUSIONS AND RECOMMENDATIONS}

\section{a. Conclusion}

Based on the results of the research and discussion it can be concluded:

1) Variables forming a work culture in South Korean companies in Indonesia, such as harmonious relations in the work culture of South Korean companies in Indonesia are better reflected in the indicators of cooperation, work integrity is better reflected with indicators of honesty while work discipline more reflected with indicators working on time.

2) The work culture of South Korean companies in Indonesia is more dominant in work integrity, which can encourage the quality and quantity of work produced.

3) South Korean companies are almost all based on the motto of ethics of harmony and Confucius, sincerity and perseverance, creativity and development.

\section{b. Suggestion}

The difference in leadership style between local employees and South Korean expatriates is caused by the South Korean expatriate leadership style is more on the autocratic leadership style, while the Indonesian leadership style is more into the paternalistic leadership style. Changing culture requires enormous effort and requires the involvement of all elements in the organization. The role of the leader is very important in shaping the organizational culture and is very decisive in the effort to achieve the goals previously set. Organizations require more roles than leaders.

The work culture will run well depending on the job. The South Korean expatriates must be able to direct, guide and influence the thoughts, feelings, actions, and behavior of local employees to be moved towards certain goals. There is direct interaction between the leadership and employees that can influence and shape certain cultural characteristics in the company that are important for the company.

\section{REFERENCES}

1. Beach, L. R. (1993). Making The Right Decision Organiztional Culture, Vision and Planning. United States of America: Prentice-Hall Inc

2. Cloud, H. (2007). Integritas-Keberanian Memenuhi Tuntutan Kenyataan. Jakarta: Gramedia Pustaka Utama

3. Darini, R. 2010. Park Chung-Hee dan Keajaiban Ekonomi Korea Selatan. Mozaik, 5(1),21-29. https://doi.org/10.21831/moz.v5i1.4336

4. Gorda, I.G.N. (2006). Manajemen Sumber Daya Manusia. Denpasar, Bali: Astabrata

5. Hakim, A. (2011). The Implementation of Islamic Leadership and Islamic Organizational Culture and Its Influence on Islamic Working Motivation and Islamic Performance PT Bank Mu'amalat Indonesia Tbk. Employee in the Central Java. Asia Pacific Management Review, 17(1):77-90

6. Hassan, M., Toylan, N.V., Semerciöz, F., \& Aksel, I. (2012). Interpersonal Trust and Its Role in Organizations. International Business Research, 5(8):33-39. DOI:10.5539/ibr.v5n8p33

7. Hwan, S.Y. (2011). Labor Relations in Korean Companies in Indonesia: Focusing on the Early Period. Kyoto Review of Southeast Asia, Issue 11:1-24

8. Kee.T.S. (2008). Influences of Confucianism on Korean Corporate Culture. Asian Profile, 36(1):9-20

9. Kessler, L.L. (2014). The Effect of Organizational Culture on It Employees Turnover Intention In Israel. Economic Science Series, 23(1):1019-1027

10. Koentjaraningrat. (2004). Kebudayaan, Mentalitas dan Pembangunan. Jakarta : PT. Gramedia Pustaka Utama

11. Lee, C.Y. (2012). Korean Culture And Its Influence on Business Practice in South Korea. The Journal of International Management Studies, 7(2):184-191

12. Lumbanraja, P. (2008). Tantangan Bagi Kepemimpinan Lintas Budaya, Jurnal Manajemen Bisnis 1(2):69-77

13. Malik, A. (2014). Pengaruh Budaya Organisasi Dan Loyalitas Kerja Dengan Intensi Turnover Pada Karyawan PT. Cipaganti Heavy Equipment Samarinda. E Journal Psikologi, 2(1):65-75

14. Mangkunegara, A.P. (2005). Manajemen Sumber Daya Manusia Perusahaan. Bandung: Remaja Rosdakarya

15. Mayangsari, D., Hamid, D. \& Prasetya, A. (2014). PerananBudayaKerja Korea Selatan Dalam Meningkatkan Kinerja Karyawan Studi pada Karyawan PT. Cheil Jedang Indonesia Pasuruan. Jurnal Administrasi Bisnis, 16(1):1-8

16. Nongo, E.S. (2012). The Influence of Corporate Culture on Employee Commitment to the Organization. International Journal of Business and Management, 7(22):1-8. DOI:10.5539/ijbm.v7n22p21 
17. Purnama, C. (2013). Influence Analysis of Organizational Culture Organizational Commitment Job and Satisfaction Organizational Citizenship Behavior (OCB) Toward Improved Organizational Performance, International Journal of Business, Humanities and Technolog3(5): 86-100. https://doi.org/10.30845/ijbht

18. Puspitasari, I., Musadieq, M.A., \& Prasetya, A. (2014). Analisis Gaya Kepemimpinan Lintas Budaya Ekspatriat (Studi Penelitian pada PT. Haier Sales Indonesia, Jakarta Utara). JurnalAdministrasiBisni,s 8(1):1-10

19. Rachmadita, R.N., Kurniasih, D., \& Sandora, R. (2011). Analisis Pengaruh Budaya Organisasi terhadap Loyalitas Karyawan dan Keterkaitannya dengan Kesehatan. Jurnal Teknik dan Manajemen Industri, 6(2):121-129

20. Rahayu, W.P. (2009). Karakteristik Budaya dan Manajemen Bisnis Korea. Jurnal Ekonomi Bisnis, 14(1):31-36

21. Rasid, S.Z.A., Manaf, M.A.A., \& Quoquab, F. (2013). Leadership and Organizational Commitment in the Islamic Banking Context: The Role of Organizational Culture as a Mediator. American Journal of Economics 3(5):171-176. DOI: $10.5923 /$ c.economics.201301.29

22. Risdanti, N. (2017). Studi Lintas Budaya Kepemimpinan Gaya Korea Di Indonesia (Pada PT. Semarang Garment). Jurnal Bisnis Strategi, 22(2): 28-44. DOI: 10.14710/jbs.22.2.28-44

23. Robbins, S.P. (2003). Organisational behaviour (10th ed). San Diego: Prentice Hall.

24. Shaban, O.S., Al-Zubi, Z., Ali, N., \& Alqotaish, A. (2017). The Effect of Low Morale and Motivation on Employees' Productivity \& Competitiveness in Jordanian Industrial Companies. International Business Research; 10(7):1-7. DOI:10.5539/ibr.v10n7p1

25. Shahzad, F., Luqman, R.A., Khan, A.R., \& Shabbir, L. (2012). Impact of Organizational Culture on Organizational Performance: An Overview. Interdisciplinary Journal Of Contemporary Research In Business 3(9): 975-985

26. Sugiartiningsih. (2017). Pengaruh Inflasi Indonesia Terhadap Penerimaan Penanaman Modal Asing Langsung Korea Selatan Di Indonesia Periode 2000-2014. Jurnal Manajemen Maranatha, 17(1):33-40. https://doi.org/10.28932/jmm.v17i1.416

27. Syafitri, M., \& Heriyanto, M. (2013). Kesadaran, Lingkungan dan Budaya Kerja, Jurnal Administrasi Pembangunan, 1(2): $129-134$

28. Wibawa, M.A., Troena, E.A., Armanu \& Noermijati. 2014. The Role of Organizational Culture on Spiritual Leadership, Human Capital, and Employee Loyalty (Study at Private Hospital in Denpasar, Bali, Indonesia). European Journal of Business and Management, 6(21):144-153. 